\title{
Perbandingan Pediatric Logistic Organ Dysfunction dan Pediatric Risk of Mortality III Sebagai Prediktor Kematian Sindrom Syok Dengue di Ruang Rawat Intensif Anak
}

\author{
Henny Rosita Iskandar, * Dharma Mulyo, * Antonius Pudjiadi, ** Agnes Pratiwi, * \\ Yuliatmoko Suryatin* \\ ${ }^{*}$ RSAB Harapan Kita, Jakarta. ${ }^{* *}$ RSUP Cipto Mangunkusumo, Jakarta
}

\begin{abstract}
Latar belakang. Sindrom syok dengue (SSD) merupakan bentuk demam berdarah dengue (DBD) berat. Mortalitas SSD pada Rumah Sakit Anak dan Bunda Harapan Kita (RSAB HK) cukup tinggi ( 13,2\% ). Tujuan. Menilai perbandingan pediatric logistic organ dysfunction (PELOD) dan pediatric risk of mortality (PRISM) III sebagai prediktor kematian SSD pada anak yang dirawat di ruang perawatan intensif anak. Metode. Penelitian prospektif, 41 anak dengan SSD yang dirawat di ruang perawatan intensif dari bulan Januari - Desember 2006 di RSAB HK dilibatkan dalam penelitian. Diagnosis SSD ditegakkan berdasarkan kriteria WHO tahun 1997 dan dikonfirmasi dengan serologi positif Dengue Blot yang dilakukan pada hari kelima demam. Perhitungan skor PELOD and PRISM III dilakukan dari hasil pemeriksaan pada hari pertama masuk ruang rawat intensif.

Hasil. Terdapat 41 subyek yang diteliti, umur dari 8 sampai 180 bulan. Kematian terjadi pada 5 anak (12,1\%). Rerata skor PELOD anak yang meninggal 22,2 dan yang hidup 7,7 sedangkan rerata skor PRISM III anak yang meninggal 22 dan yang hidup 9,4. Analisa skor PELOD dan PRISM III menurut MannWhitney $U$ test terdapat perbedaan bermakna antara anak yang meninggal dan hidup dengan $\mathrm{p}=0,001$ untuk PELOD dan $\mathrm{p}=0,005$ untuk PRISM III. Kurva receiver operating characteristic (ROC) dengan CI 95\% 0,953 untuk PELOD dan 0,889 untuk PRISM III.

Kesimpulan. Skor PELOD dan PRISM III merupakan alat yang baik untuk memprediksi kematian pasien anak SSD yang dirawat di ruang intensif anak. Skor PELOD sedikit lebih baik dari skor PRISM III.

Sari Pediatri 2011;12(6):440-6.
\end{abstract}

Kata kunci: PELOD, PRISM III, SSD, ruang intensif anak.

Alamat korespondensi:

Dr. Henny Rosita Iskandar, Sp.A. Staf PICU RSAB Harapan Kita. Jl. Letjen S. Parman Kav. 87, Slipi, Jakarta Barat. DKI Jakarta. Telp. 02156960053. E-mail: henny.rosita@yahoo.com
I ndonesia dikategorikan oleh WHO sebagai negara dengan status 'A' karena infeksi virus dengue masih merupakan masalah kesehatan masyarakat. Masalah infeksi virus dengue menyebabkan anak perlu dirawat di rumah sakit 
karena dapat menyebabkan kematian, terjadi siklus epidemik pada daerah perkotaan yang menyebar ke daerah pinggiran, dan terdapat mulitipel serotipe virus yang beredar di masyarakat. Sejak tahun 2007, Indonesia merupakan negara dengan jumlah kasus DBD terbanyak di dunia yaitu lebih dari 155.000 kasus pertahun selama 3 tahun terakhir. Case fatality rate (CFR) DBD di Indonesia cukup tinggi, mencapai 4,6\% pada tahun $1987,2 \%-3 \%$ pada tahun 1991-1999, dan menurun menjadi kurang dari 2\% sejak tahun 2000. Dilaporkan CFR yang terendah dicapai pada tahun 2008 yaitu $0,6 \%$. Berdasarkan data dari WHO, CFR/ DBD beberapa negara pada tahun 2009 sebagai berikut Indonesia $0,89 \%$, Thailand $0,01 \%$, India $0,62 \%$, and Sri Lanka $0,99 \% .{ }^{1}$ Apabila dinilai dari kasus SSD, CFR di Indonesia sekitar 13\%-19,7\%. ${ }^{2}$

\section{Skor PRISM III}

Skor PRISM III mempunyai kemampuan membedakan prognosis pasien (misalnya kematian) dengan pasien yang tidak akan meninggal. Kemampuan memprediksi kematian ini dijelaskan oleh besarnya area di bawah ROC, Besar area di bawah ROC skor PRISM III adalah 0,944 $\pm 0,021$ (daerah di bawah $R O C \pm S E M$ ). Selain kemampuan membedakan ini, skor PRISM III juga mempunyai kemampuan untuk memprediksi kemungkinan pasien meninggal pada berbagai tingkat skor. Kemampuan tersebut dihitung/analisis secara statistik dengan Hosmer Lemeshow goodness of fit test. Nilai $\mathrm{p}=0,05$ dianggap berbeda bermakna secara statistik antara apa yang diprediksi dengan apa yang terjadi. Secara tradisional, kemampuan untuk memprediksi pada berbagai tingkat skor/interval risiko dianggap baik bila nilai $\mathrm{p}$ lebih besar dari 0,1 , sedangkan skor PRISM III mempunyai nilai $\mathrm{p}=0,55$ (12 df). Skor PRISM III dipublikasikan pada tahun 1996 dan dapat digunakan untuk pasien penyakit kritis pada neonatus, bayi, anak-anak, dan remaja, tetapi bukan untuk bayi prematur atau dewasa. Skor PRISM III terdiri dari 17 variabel/tanda meliputi sistem kardiovaskular, syaraf, fungsi vital, status asam basa, pemeriksaan kimiawi, pemeriksan hematologi, dan faktor lain seperti status operasi dan beberapa penyakit tertentu. Skor PRISM III tidak dapat digunakan pada penyakit spesifik tertentu seperti fulminant hepatic failure, gagal ginjal akut, sakit kritis karena tenggelam, kanker, atau pasien transplantasi sumsum tulang. Skor PRISM III telah digunakan secara luas di Amerika Utara dan telah divalidasi dengan subyek penelitian yang besar pada berbagai ruang rawat intensif anak yang berbeda. Skor PRISM III telah dipatenkan dan bagi yang mau menggunakan skor ini harus membayar untuk mendapatkan rumus menghitung besarnya kemungkinan pasien meninggal., 3

Tingkat kematian pasien penyakit kritis pada ruang rawat intensif anak lebih kecil dari tingkat kematian pada ruang rawat intensif dewasa, sehingga penelitian yang menggunakan luaran kematian akan memerlukan jumlah subyek penelitian yang besar. Untuk menghindari keadaan tersebut, beberapa dokter anak intensivist mengembangkan suatu alat untuk memperkirakan beratnya disfungsi organ pasien sebagai surrogate marker (penanda pengganti). Mereka melakukan program penelitian untuk menciptakan dan melakukan validasi sistem skor untuk menilai derajat gangguan sistem organ. Sistem skor tersebut diberi nama pediatric logistic organ dysfunction (PELOD). Studi pengembangan PELOD melibatkan 594 pasien termasuk 51 pasien yang meninggal. Dari studi pengembangannya, didapatkan 6 sistem organ dengan 12 variabel yang dipertahankan untuk menilai derajat penyakit. Ke enam sistem organ itu adalah 1. Sistem pernafasan dengan variabel $\mathrm{PaO}_{2}$, $\mathrm{PaCO}_{2}$, dan penggunaan ventilasi mekanik; 2 . Sistem kardiovaskular dengan variabel denyut jantung dan tekanan sistolik; 3. Sistem syaraf dengan variabel Glasgow coma scale dan reaksi pupil; 4. Sistem hepatik dengan variabel SGOT dan prothrombin time; 5 . Sistem ginjal dengan variabel kreatinin; 6. Sistem hematologi dengan variabel hitung leukosit dan trombosit. Semua variabel diukur minimal satu kali, apabila diukur lebih dari satu kali dalam 24 jam maka nilai yang digunakan adalah nilai yang terburuk. Poin maksimal untuk sistem organ kardiovaskular dan syaraf 20 poin PELOD, sedangkan nilai terbesar untuk sistem organ lainnya sebesar 10 poin PELOD. Maksimal skor PELOD adalah 71 poin.

Rumus untuk menghitung kemungkinan meninggal adalah:

\section{Probality $_{\text {death }}=1:\left(1+\exp \left[7 \cdot 64-0 \cdot 30^{*}\right.\right.$ PELOD score $\left.]\right)$}

Skor PELOD mempunyai keunggulan lain dari skor PRISM III yaitu dapat menggambarkan banyak dan derajat sistem organ yang terganggu serta dapat digunakan secara gratis. ${ }^{5}$ 
Tujuan penelitian untuk menilai perbandingan pediatric logistic organ dysfunction (PELOD) dan pediatric risk of mortality ( PRISM ) III sebagai prediktor kematian SSD pada anak yang dirawat di Ruang Perawatan Intensif Anak.

\section{Metode}

Penelitian prospektif melibatkan pasien anak dengan diagnosis SSD dari Januari - Desember 2006 yang di rawat di Ruang Intensif Anak RSAB HK. Diagnosis SSD ditegakkan sesuai kriteria WHO tahun $1997^{6}$ dan dikonfirmasi dengan sero positif dengue blot yang diperiksa pada hari kelima demam. Skor PELOD dan PRISM III dihitung dari pemeriksaan yang dilakukan pada hari pertama di rawat di Ruang Intensif Anak. Analisis statistik dilakukan dengan program Statistical Package for Social Science (SPSS) versi 11. Perbandingan skor proporsi kematian dilakukan dengan chi-square test, nilai p kurang dari 0,05 dianggap bermakna secara statistik. Kemampuan membedakan data skor pasien antara yang hidup dan yang meninggal dilakukan dengan menggunakan kurva receiver operating characteristic (ROC). Analisis skor antara pasien yang diperkirakan meninggal dengan kematian yang terjadi dibagi dalam 5 interval risiko dengan Hosmer-lemeshow goodness-of fit test. ${ }^{7}$ Secara tradisional, kemampuan untuk memprediksi pada berbagai tingkat skor dianggap baik bila nilai $\mathrm{p}$ lebih besar dari 0,1. Penelitian sudah disetujui Komite Etik Medis RSAB Harapan Kita dan sebelum subyek diteliti dimintakan informed consent dari orang tua pasien.

\section{Hasil}

Telah diteliti 41 anak dengan diagnosis SSD yang dirawat di Ruang Rawat Intensif Anak RSAB HK dari bulan Januari-Desember 2006. Subyek penelitian yang terdiri dari $52 \%$ perempuan dan $48 \%$ laki-laki, umur bervariasi dari $8-180$ bulan, rerata umur 80 bulan dan deviasi standar 40 bulan. Ditemukan 5 orang (12,1\%) meninggal, rerata lama perawatan 3,88 hari. Tigapuluh satu subyek merupakan rujukan dari instalasi gawat darurat dan 10 subyek berasal dari ruang perawatan anak. Berdasarkan hasil pemeriksaan dari dengue blot, 3(7\%) subyek mendapatkan infeksi dengue primer (IgM positif dan Ig G negatif) dan 38(93\%) subyek mendapatkan infeksi dengue sekunder (IgM dan IgG positif). Berdasarkan gangguan fungsi organ yang terjadi, 23 (56\%) subyek mengalami gangguan fungsi hati, $22(54 \%)$ subyek dengan gangguan fungsi hematologi, 13 (32\%) subyek dengan gangguan fungsi syaraf, 17 (41\%) subyek dengan gangguan fungsi respirasi, $11(27 \%)$ subyek dengan gangguan fungsi kardiovaskular, dan hanya $2(5 \%)$ subyek dengan gangguan fungsi ginjal (Tabel 1).

Rerata skor PRISM III untuk subyek yang meninggal 22 dan yang hidup sebesar 9,4 sedangkan skor PELOD untuk subyek yang hidup sebesar 22,2 dan yang hidup sebesar 7,7. Analisis statistik dengan Mann-Whitney $U$ test terhadap skor PELOD subyek yang hidup dan meninggal berbeda bermakna ( $\mathrm{p}=0,001)$, skor PRISM III juga berbeda bermakna dengan $\mathrm{p}=0,005$. Daerah di bawah $R O C$ curve $C I$ 95\% untuk PELOD 0,953 dan PRISM III 0,889 (Gambar 1).

Tabel 1. Karakteristik umum subyek penelitian

\begin{tabular}{ll}
\hline Karakteristik & $\mathrm{n}(\%)$ \\
\hline Jumlah subyek & 41 \\
Kematian, n (\%) & $5(12)$ \\
Umur (bulan) & \\
$\quad$ Rentang umur & $8-180$ \\
$\quad$ Median & 80 \\
Rerata lama rawat di ruang rawat intensif & 3.88 \\
anak (hari) & \\
Jenis infeksi dengue, n (\%) & \\
$\quad$ Primer & $3(7)$ \\
$\quad$ Sekunder & $38(93)$ \\
Jenis kelamin, n (\%) & \\
$\quad$ Wanita & $22(54)$ \\
$\quad$ Laki-laki & $19(46)$ \\
Asal rujukan, n (\%) & \\
$\quad$ Instalasi gawat darurat & $31(76)$ \\
$\quad$ Ruang rawat anak & $10(24)$ \\
Gangguan fungsi organ, n (\%) & \\
$\quad$ Kardiovaskular & $11(27)$ \\
Respirasi & $17(41)$ \\
Syaraf & $13(32)$ \\
Hepatik & $23(56)$ \\
Ginjal & $2(5)$ \\
Hematologi & $22(54)$ \\
\hline
\end{tabular}


ROC Curve

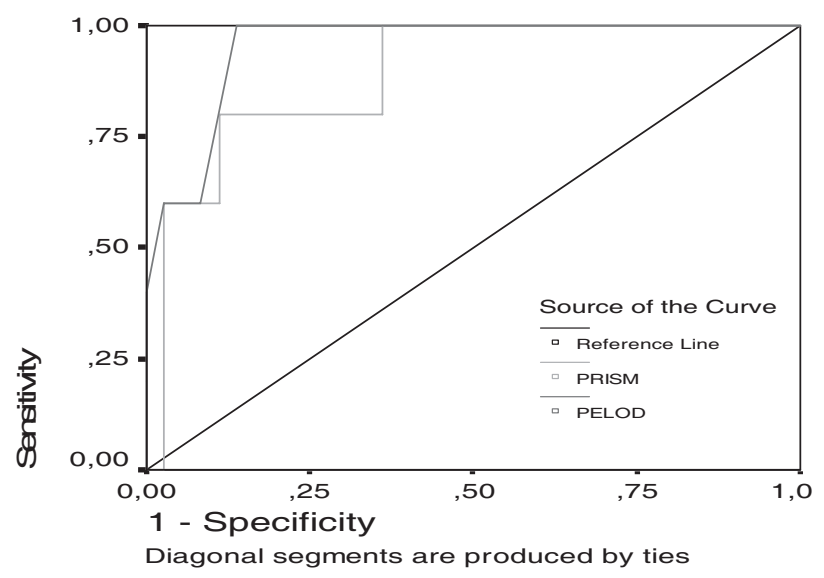

Berdasarkan kalibrasi skor PRISM III yang dibagi dalam 5 interval risiko kematian, nilai harapan kematian dari hasil perhitungan tidak berbeda banyak dengan kematian yang terjadi, kecuali untuk interval skor PRISM III >15-30, dari perhitungan didapatkan harapan kematian 1,2 sedangkan kematian terjadi pada 4 subyek. Kalibrasi skor PELOD dalam 5 interval risiko kematian didapatkan nilai perhitungan harapan kematian setiap interval tidak berbeda banyak dengan kenyataan kematian yang terjadi (Tabel 2).

Delapan anak menderita empat gangguan fungsi organ, dan lima subyek meninggal (Tabel 3) dengan gangguan fungsi respirasi. Masing-masing punya nilai skor PELOD 1 poin; 3 subyek menderita gangguan fungsi syaraf dengan nilai skor PELOD 10, 10,

Gambar 1. Curve ROC skor PRISM dan PELOD

Tabel 2. Model kalibrasi dalam lima interval risiko kematian

\begin{tabular}{lcccccc}
\hline & \multirow{2}{*}{ Interval skor } & $\mathrm{n}$ & \multicolumn{2}{c}{ Hidup } & \multicolumn{2}{c}{ Meninggal } \\
\cline { 4 - 7 } & & & Observed & Expected & Observed & Expected \\
\hline PRISM III & 01 & 3 & 3 & 3 & 0 & 0 \\
& $>1-5$ & 11 & 11 & 10,8 & 0 & 0,2 \\
& $>5-15$ & 19 & 18 & 17,6 & 1 & 1,4 \\
& $>15-30$ & 7 & 3 & 5,8 & 4 & 1,2 \\
& $>30$ & 1 & 1 & 0,6 & 0 & 0,4 \\
\hline Total & $0-1$ & 71 & 36 & 37,8 & 5 & 3,2 \\
\hline PELOD & $>1-5$ & 11 & 11 & 10,6 & 0 & 0 \\
& $>5-15$ & 18 & 16 & 16,4 & 2 & 0,4 \\
& $>15-30$ & 3 & 2 & 2,0 & 1 & 1,6 \\
& $>30$ & 2 & 0 & 0,8 & 2 & 1 \\
\hline Total & & 41 & 36 & 36,8 & 5 & 4,2 \\
\hline
\end{tabular}

Tabel 3. Jumlah organ yang terganggu, menurut skor PELOD terhadap kematian

\begin{tabular}{cccccc}
\hline \multirow{2}{*}{ Disfungsi organ } & $\mathrm{n}$ & Hidup & Meninggal & \multicolumn{2}{c}{ Rerata skor PELOD } \\
\hline 0 & 1 & 1 & 0 & 0 & Meninggal \\
1 & 6 & 6 & 0 & 4,33 & - \\
2 & 16 & 16 & 0 & 6,56 & - \\
3 & 10 & 10 & 0 & 11 & - \\
4 & 8 & 3 & 5 & 16 & - \\
5 & 0 & 0 & 0 & - & - \\
\hline
\end{tabular}

Sumbu Y menunjuk besarnya prosentasi kematian subyek pada tiap kategori

Sumbu X menunjukkan skor dari tiap gangguan dan jumlah subyek

Tabel 4. Rerata skor PELOD dan PRISM III berdasarkan asal pasien

\begin{tabular}{lcccc}
\hline & \multicolumn{2}{c}{ IGD (31 pasien) } & \multicolumn{2}{c}{ Ruang perawatan (10 pasien) } \\
\cline { 2 - 5 } & Hidup & Meninggal & Hidup & meninggal \\
\hline Skor PELOD & 6,95 & 22,2 & 9,7 & - \\
Skor PRISM III & 10,01 & 22 & 7,3 & - \\
\hline
\end{tabular}


dan 20 poin; 3 subyek menderita gangguan fungsi kardiovaskular dan masing-masing punya nilai skor 10 poin; 2 subyek menderita gangguan fungsi hematologi dan masing-masing mempunyai nilai 1 poin; 2 subyek menderita gangguan fungsi ginjal dan masing=masing punyai nilai 10 poin (Gambar 2 ).

Semua suyek yang meninggal (5 pasien) berasal dari Instalasi Gawat Darurat. Perbedaan proporsi pasien yang meninggal dilihat dari asal subyek (IGD dan ruang rawat $R S)$ tidak berbeda bermakna $(p=0,31)$.
Berdasarkan asal dari subyek, 31 subyek dari IGD mempunyai rerata skor PELOD 9,4 sedangkan rerata skor PRISM III adalah 12. Subyek berasal dari IGD yang hidup mempunyai rerata skor PELOD 6,95 dan skor PRISM III adalah 10,01. Pasien meninggal mempunyai nilai skor PELOD 22,2 dan skor PRISM III 22. Rerata skor PELOD 10 subyek yang dirujuk dari ruang perawatan rumah sakit semua hidup dan mempunyai rerata skor PELOD 9,7 dan skor PRISM III 7,3 (Tabel 4).
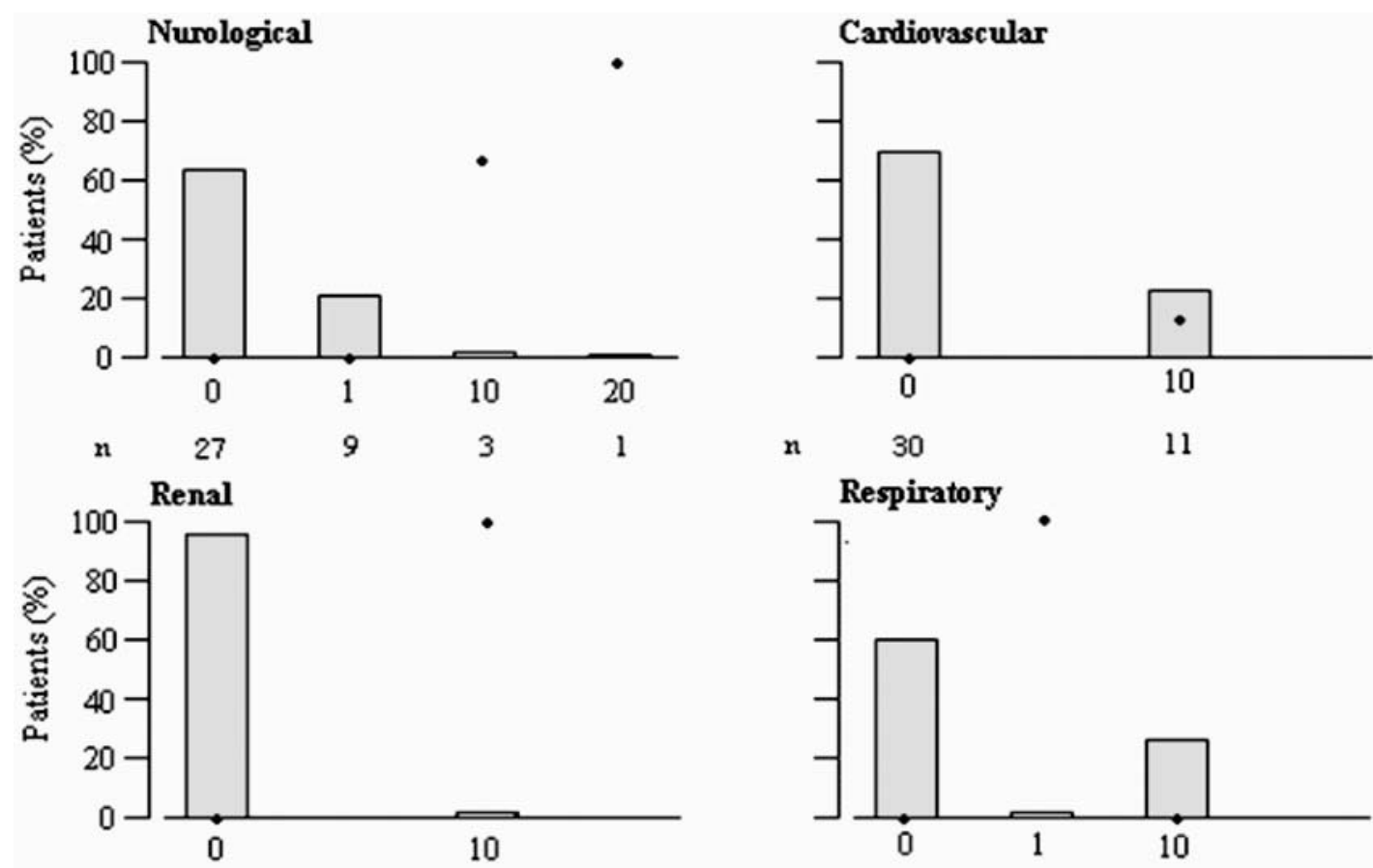

n

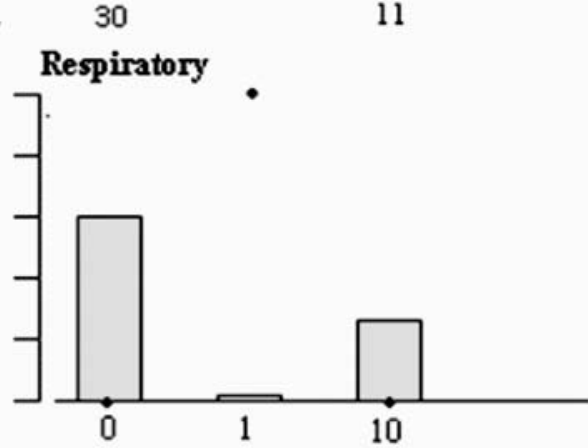

n $\quad 39$

2

n

22

5

14
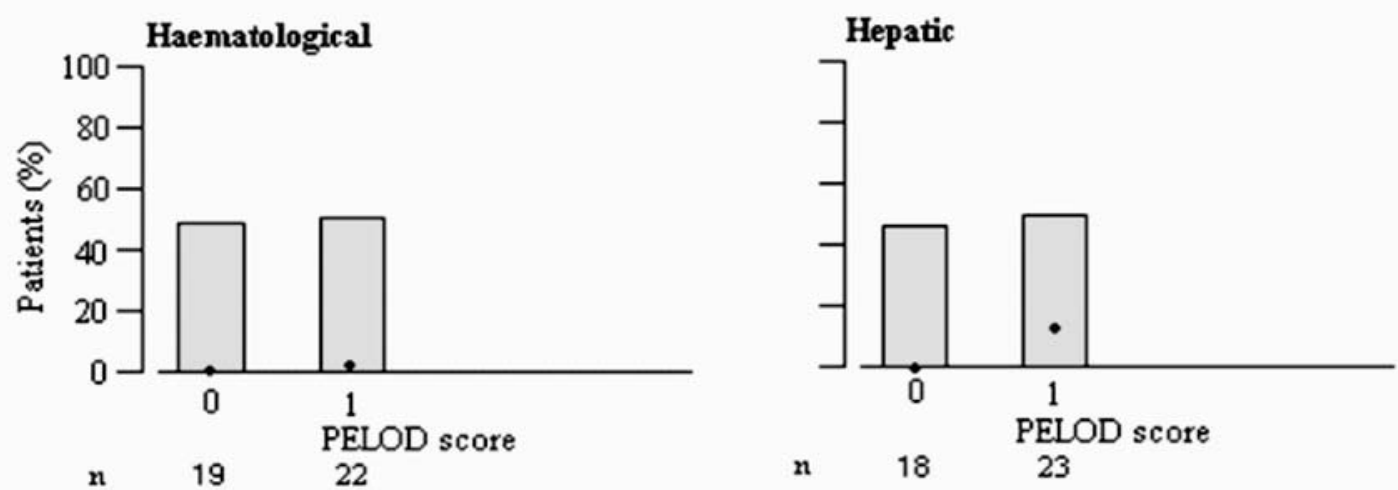

Patients' distribution and mortality rate for each organ dysfunction score Black diamonds=mortality rate, $\mathrm{N}=$ roumber of patients.

Gambar 2. Distribusi subyek berdasarkan derajat gangguan organ dan mortalitas 


\section{Pembahasan}

Tujuan penelitian untuk menilai kemampuan skor PELOD dan PRISM III memprediksi kematian pasien SSD yang dirawat di Ruang Rawat Intensif Anak. Penelitian oleh Leteurtre dan Lacroix $\mathrm{dkk}^{4,5}$ melaporkan bahwa skor PELOD dan skor PELOD yang diukur harian valid untuk menilai derajat penyakit, jumlah, dan derajat gangguan fungsi organ. Pollack $\mathrm{dkk}^{3} \mathrm{dan}$ Leteurtre ${ }^{5}$ mendapatkan kemampuan diskriminasi yang ditandai dengan area di bawah ROC skor PRISM III dan Skor PELOD, masing-masing 0,944 dan 0,91. Penelitian Qureshi $\mathrm{dkk}^{8}$ yang membandingkan skor PELOD, PRISM III, dan PIM 2 pada 101 pasien PICU (segala macam penyakit termasuk pasien bedah) sebuah rumah sakit di Pakistan mendapatkan PRISM III dan PIM 2 lebih baik dari PELOD, PRISM III mempunyai kalibrasi $\mathrm{x}^{2}=7,49$ dan $\mathrm{p}=0,49$, diskriminasi dengan area di bawah ROC 0,78, dan standardized mortality rate (SMR) 1,47; PIM 2 dengan kalibrasi $\mathrm{x}^{2}=9,65$ dan $\mathrm{p}=0,29$, diskriminasi dengan area di bawah ROC 0,88, dan SMR 1,4; PELOD dengan kalibrasi $x^{2}=20,3$ dan $\mathrm{p}=0,006$, diskriminasi dengan area di bawah ROC 0,77 , dan SMR 1,57. Analisis yang dilakukan dengan mengeluarkan pasien dengan kelainan jantung pada penelitian Qureshi dkk ini didapatkan area di bawah ROC yang lebih baik yaitu 0,813 untuk PRISM III, 0,792 untuk PELOD. Penelitian Thukral $\mathrm{dkk}^{9}$ yang meneliti 209 pasien PICU (tanpa pasien bedah) di India, didapatkan skor PELOD mempunyai area di bawah ROC 0,80. Pada penelitian kami didapatkan skor PELOD mempunyai area di bawah ROC lebih besar yaitu 0,953 sedangkan skor PRISM III mempunyai area di bawah ROC 0,889 .

Mortalitas di ruang rawat intensif ini secara umum dipengaruhi oleh sistem medis yang ada dan ko-morbid pasien yang dapat mempengaruhi mortalitas secara bervariasi. Sistem medis disini termasuk jumlah dan kecanggihan peralatan dan jumlah serta keterampilan personel termasuk pengalaman klinik. Sedangkan komorbid dapat memperbesar mortalitas seperti sepsis atau yang memperkecil mortalitas seperti pasien pasca operasi tertentu. Ruang PICU RSAB Harapan Kita sebagai bagian dari rumah sakit pemerintah Indonesia dari negara berkembang, skor PELOD mempunyai kemampuan diskriminasi (area di bawah ROC sebesar 0,953) dan kemampuan kalibrasi (observed death kelompok risiko individu tertentu hanya sedikit lebih besar dari expected death ) yang cukup baik.
Tidak banyak publikasi penelitian SSD anak yang dirawat di ruang intensif anak, sedangkan publikasi penelitian mengenai perbandingan skor PELOD dan PRISM III pada SSD yang dirawat di ruang rawat intensif anak belum ada. Sangat sukar melakukan perbandingan hasil penelitian mengenai jumlah dan beratnya gangguan fungsi organ/kematian pada subpopulasi SSD dengan metode atau kriteria yang berbeda. Penelitian oleh Gerardin dkk, ${ }^{10}$ membandingkan skor PELOD dengan skor PRISM III hanya pada penyakit malaria di Afrika dengan median skor PELOD untuk yang hidup 11 dan yang meninggal 12,5 dengan $\mathrm{p}=\leq 0,02$ sedangkan skor PRISM III untuk yang hidup 10 dan meninggal 15 dengan $\mathrm{p}=\leq 0,001$. Penelitian kami menunjukan perbedaan skor yang lebih besar antara kelompok yang hidup dan meninggal (PELOD 7,7 vs 22,2 dan PRISM III 9,4 vs 22).

Berdasarkan banyaknya fungsi organ yang terganggu, sistem organ yang paling banyak terganggu adalah sistem hepatik (56\%), diikuti oleh sistem hematologi (54\%), respirasi $(41 \%)$, syaraf (32\%), kardiovaskular (27\%), dan ginjal (5\%). Penelitian oleh Khilnani ${ }^{11}$ melaporkan bahwa $100 \%$ subyek menderita gangguan sistem kardiovaskular, diikuti oleh sistem respirasi (80\%), syaraf (75\%), hepatik (55\%), dan ginjal (50\%). Kamath dan Ranjit ${ }^{12}$ yang meneliti pasien SSD di India, berdasarkan sindrom disfungsi organ multipel, ditemukan $36.6 \%$ dari 73 subyek gangguan fungsi hepatik.

Semua subyek yang meninggal dari ruang perawatan intensif anak berasal dari IGD dan tak ada yang dari ruang perawatan anak. Terdapat perbedaan proporsi kematian dari subyek yang dirujuk dari IGD dan dari ruang rawat RSAB HK (5 dari 26 subyek yang dirujuk dari IGD dibandingkan tak ada yang meninggal dari 10 subyek yang dirujuk dari ruang rawat RS), namun perbedaan ini tidak bermakna. Diperlukan jumlah subyek penelitian yang lebih besar untuk dapat menyimpulkan perbedaan.

Dari penelitian kami didapatkan skor PELOD dan skor PRISM III menunjukkan kemampuan mendiskriminasi/ membedakan antara subyek yang akan meninggal dengan yang tidak, kemampuan skor PELOD sedikit lebih baik dari skor PRISM III.

\section{Daftar pustaka}

1. WHO. Situation update of dengue in the SEA region 2010. Diunduh dari www.searo.who.int pada tanggal 23 
Henny Rosita Iskandar dkk: Perbandingan PELOD dan PRISMIII sebagai prediktor kematian SSD di ruang rawat intensif anak

Oktober 2010.

2. Hadinegoro SR, Purwanto SH, Chatab F. Dengue shock syndrome: clinical manifestation, managemen and outcome - a hospital-base study in Jakarta, Indonesia. Dengue Buletin 1999; 23.

3. Pollack MM, Patel KM, Ruttimann UE. PRISM III: an update pediatric risk of mortality score. Crit Care Med 1996; 24: 743-52.

4. Lacroix J, Cotting J, For the pediatric acute lung injury and sepsis investigators (PALISI) network. Severity of illness and organ dysfunction scoring in children. Pediatr Crit Care Med 2005; 6: S126-34.

5. Leteurtre S, Martinot A, Duhamel A, Proulx F, Grandbastien B, Cotting J, Gottesman R, dkk. Validation of the paediatric logistic organ dysfunction (PELOD) score: prospective, observational, multicentre study. Lancet 2003; 362: 192-7.

6. WHO. Dengue haemorrhagic fever, diagnosis, treatment, prevention and control. Second edition. Geneva: WHO. 1997. Didapat dari: http://www.who.int World Health Organization. (Accessed on 23rd October 2010).

7. Lameshow S, Hosmer DW. A review of goodness of fit statistics for use in the development of logistic regression models. Am J Epidemiol 1982;115:92-102.

8. Qureshi AU, Ali AS, and Ahmad TM. Comparison of three prognostic scores (PRISM, PELOD, and PIM 2) at pediatric intensive care unit under Pakistani circumstances. J Ayub Med Coll Abbottabad 2007;19:4953.

9. Thukral A, Kohli U, Lodha R, Kabra SK, dan Arora NK. Validation of the PELOD score for multiple organ dysfunction $\mathrm{n}$ children. Indian Pediatrics 2007; 44: 683-6.

10. Gerardin P, Rogier C, Amadau S, Jouvencel P, Diatta B, Imbert P. Outcome of life-threatening malaria in African children requiring endotrachea intubation. Malar J 2007;6:51-9.

11. Khilnani P, Sarma D, Zimmerman J. Epidemiology and peculiarities of pediatric multiple organ dysfunction syndrome in New Delhi, India. Intensive Care Med 2006; 32:1856-62.

12. Kamath SR, Ranjit S. Clinical feature, complications and atypical manifestations of children with severe forms of dengue hemorrhagic fever in South India. Indian J Pediatr 2006;73:889-95. 